\title{
DAYA HAMBAT EKSTRAK BIJI MENGKUDU TERHADAP PERTUMBUHAN BAKTERI STREPTOCOCCUS MUTANS
}

\author{
Wawan Ariyanto ${ }^{1}$, Sadimin $^{\bowtie 2}$, Sariyem $^{3}$
}

\begin{abstract}
ABSTRAK
Salah satu masalah dalam rongga mulut adalah karies gigi. Karies gigi disebabkan karena adanya bakteri Streptococcus mutans. Biji mengkudu merupakan salah satu tanaman herbal yang mempunyai efek antibakteri yang tersusun asam linoleat dan asam lemak esensial, alkaloid, saponin, tannin dan glikosida jantung. Tujuan penelitian ini adalah untuk mengetahui daya hambat ekstrak biji mengkudu terhadap pertumbuhan bakteri Streptococcus mutans.

Jenis penelitian ini menggunakan metode deskriptif. Rancangan penelitian ini adalah Eksperimental. Penelitian ini menggunakan konsentrasi $100 \%$ dan 8 kali pengulangan. Menggunakan kelompok kontrol Natrium Fisiologis 0,9\%. Subyek penelitian dalam penelitian ini adalah bakteri Streptococcus mutans. Pada penelitian ini bakteri yang telah ditumbuhkan pada media PCA diberi paper disk yang sebelumnya telah dicelupkan ke dalam air ekstrak biji mengkudu 100\%, lalu mengambil paper disk kembali dicelupkan ke Natrium Fisiologis 0,9\% sebagai kelompok kontrol dan di letakkan pada media PCA, kemudian diinkubasi selama 1 x 24 jam. Setelah itu dilakukan pengukuran pada daerah oligodinamik dengan jangka sorong (mm). Analisa data yang digunakan adalah deskriptif kuantiatif.

Hasil penelitian menunjukkan bahwa ekstrak biji mengkudu mampu menghambat pertumbuhan bakteri Streptococcus mutans. Walaupun memiliki daya hambat masih tergolong sangat lemah yaitu rata-rata dari 8 kali percobaan adalah $8,32 \mathrm{~mm}$ dan diharapkan penelitian ini dapat dikembangkan kembali dengan metode lain, supaya hasil yang di dapatkan maksimal.
\end{abstract}

Kata kunci : Karies gigi, Streptococcus mutans, Ekstrak biji mengkudu

\begin{abstract}
One of the problems in the oral cavity are dental caries. Dental caries is caused by bacteria Streptococcus mutans. Mengkudu seed is one of the herbs that have antibacterial effects that is composedof linoleic acid and essential fatty acids, alkaloids, saponins, tannins and cardiac glycosides. The purpose of this study was to determine the inhibitory Mengkudu seed extract on the growth of Streptococcus mutans.

This research uses descriptive method. The study design is experimental. This study uses a concentration of $100 \%$ and 8 repetitions. Using a control group Sodium Physiological 0.9\%. Research subjects in this study is the bacteria Streptococcus Mutans. In this study, bacteria were grown on PCA media by paper disc which had previously been dipped in water 100\% noni seed extract, then take a paper disk back Sodium Physiological dipped $0.9 \%$ as a control group and in place on the media PCA, then incubated for $1 \times 24$ hours. Once it is done in the area oligodinamik measurements with calipers ( $\mathrm{mm}$ ). Analysis of the data used is descriptive kuantiatif.

The results showed that noni seed extract can inhibit the growth of bacteria Streptococcus mutans. While having inhibitory still relatively very weak which is an average of 8 times the experiment is $8.32 \mathrm{~mm}$ and it is hoped this research can be developed again with another method, in order to get results in maximum.
\end{abstract}

Keywords : Dental caries, Streptococcus mutans, noni seed extract

${ }^{1)}$ Mahasiswa Jurusan Keperawatan Gigi Poltekkes Kemenkes Semarang

${ }^{2,3)}$ Dosen Jurusan Keperawatan Gigi Poltekes Kemenkes Semarang

$\bowtie$ : sadimingolden@gmail.com 


\section{PENDAHULUAN}

Kesehatan adalah keadaan sehat, baik secara fisik, mental, spiritual maupun sosial yang memungkinkan setiap orang untuk hidup, produktif secara sosial dan ekonomis. Upaya kesehatan adalah setiap kegiatan atau serangkaian kegiatan yang dilakukan secara terpadu, terintregasi dan berkesinambungan untuk memelihara dan meningkatkan derajat kesehatan masyarakat dalam bentuk pencegahan penyakit, peningkatan kesehatan, pengobatan penyakit dan pemulihan kesehatan oleh pemerintah atau masyarakat. Pelayanan kesehatan meliputi promotif, preventif, kuratif dan rehabilitative (Depkes RI, 2009).

Rongga mulut merupakan pintu gerbang yang sangat penting bagi kita karena semua makanan atau minuman yang masuk kedalam tubuh, harus melalui rongga ini. Untuk melaksanakan fungsinya ini rongga mulut dilengkapi oleh sejumlah besar bakteri yang akan berhubungan dengan mukosa atau jaringan lunak permukaan rongga mulut. Tahukah Anda kalau ternyata ada begitu banyak bakteri yang hidup dalam rongga mulut kita. Bakteri tersebut bermacammacam dan sangat kompleks. Bakteri tersebut secara umum terbagi atas dua yaitu bakteri aerob (bakteri yang butuh oksigen untuk hidup) dan bakteri an aerob (tidak butuh oksigen) (Anonim, 2010).

Gigi berlubang merupakan satu dari penyakit manusia yang paling umum terjadi. Penyakit ini merupakan penyakit jaringan gigi yang ditandai dengan kerusakan jaringan, dimulai dari permukaan email gigi dan meluas kearah pulpa. Di Indonesia, penderita gigi berlubang tidaklah sedikit. Hasil Riset Kesehatan Dasar (2013), menunjukkan bahwa prevalensi nasional bermasalah gigi dan mulut adalah 25,9\%, sebanyak 14 provinsi mempunyai prevalensi masalah gigi dan mulut diatas angka nasional (Depkes RI, 2013). Streptococcus mutans menjadi yang paling banyak menyebabkan gigi berlubang di seluruh dunia dari semua Streptococcus oral yang lain. Streptococcus mutans, bertahan hidup dari suatu kelompok karbohidrat yang berbeda. Saat gula yang dimetabolisme dan sumber energi lainnya, mikroba menghasilkan asam yang menyebabkan rongga di gigi (Nugraha, 2008).

Streptococcus mutans biasanya ditemukan pada rongga gigi manusia yang luka dan menjadi bakteri yang paling kondusif menyebabkan karies untuk email gigi. Streptococcus mutans adalah bersifat asidogenik yaitu menghasilkan asam, asidodurik, mampu tinggal pada lingkungan asam, dan menghasilkan suatu polisakarida yang lengket disebut dextran. Oleh karena kemampuan ini, Streptococcus mutans bisa menyebabkan lengket dan mendukung bakteri lain menuju ke email gigi, lengket mendukung bakteri-bakteri lain, pertumbuhan bakteri asidodurik yang lainnya, dan asam melarutkan email gigi (Nugraha, 2008).

Pengobatan secara tradisional menggunakan bahan-bahan alami semakin banyak diminati karena ketersediaan dan harganya yang terjangkau. Selain itu, menurut beberapa penelitian, obat tradisional tidak banyak menimbulkan efek samping seperti obat kimia bahkan ada yang tidak menimbulkan efek samping sama sekali, asalkan digunakan secara tepat. Pemakaian tanaman obat untuk menangani penyakit dipercaya dapat memberikan efek kesembuhan secara menyeluruh dan maksimal. Pemakaian bahan herbal alami lebih mendorong dan mengoptimalkan tubuh untuk melakukan penguatan diri saat menghadapi penyakit (Kariman, 2014).

Di dalam buah mengkudu terkandung zat-zat yang berkaitan dengan kesehatan dan telah dibuktikan hanya terdapat di dalam mengkudu. Tanaman mengkudu mengandung berbagai vitamin, mineral, enzim alkaloid, kofaktor dan sterol tumbuhan yang terbentuk secara alamiah (Djauhariya dan Rosman, 2000).

Selain buahnya yang mengandung manfaat, bijinya ternyata juga memiliki manfaat. Bahkan, biji buah mengkudu ini 
pun memiliki khasiat .Sementara biji mengkudu yang kaya akan asamlinoleat, asam lemak esensial, bermanfaat melembabkan kulit (Anonim, 2012). Biji mengkudu berwarna cokelat kehitaman, berukuran kecil dan pipih. Didalam biji mengkudu terdapat alkaloid, saponin, tanin dan glikosida jantung (Hayani dan Fatimah, 2004).

Dari beberapa kandungan yang terdapat pada biji mengkudu, yang bersifat antibakteri adalah tannin dan saponin. Tanin memiliki aktivitas antibakteri, secara garis besa mekanisme yang diperkirakan adalah toksisitas tannin dapat merusak membrane sel bakteri (Bayu, dkk, 2008). Sedangkan saponin mempunyai efek antibakteri dan anti jamur yang bagus. Efek anti jamur dan anti bakteri terganggu dengan adanya gugus monosakarida dan turunannya. Saponin dapat berfungsi sebagai detergen (Dewi, 2009)

Pada penelitian ini peneliti akan menguji di study laboratorium tentang daya hambat ekstrak biji mengkudu terhadap bakteri Streptococcus mutans, dengan tujuan untuk mengetahui pengaruh ekstrak biji mengkudu sebagai penghambat pertumbuhan bakteri Streptococcus mutans. Mengetahui daerah oligodinamik (bebas bakteri) ekstrak biji mengkudu terhadap pertumbuhan bakteri Streptococcus mutans. Mengetahui perbedaan pertumbuhan bakteri Streptococcus mutans antara kelompok perlakuan (ekstrak biji mengkudu) dan kelompok kontrol (natrium fisiologis).

\section{METODE PENELITIAN}

Metode penelitian yang digunakan dalam penelitian ini adalah experimental. Penelitian ini dilakukan untuk mendapatkan gambaran tentang suatu keadaan secara obyektif dimana variabel sebab atau resiko dan akibat atau kasus yang terjadi pada obyek penelitian akan diukur atau dikumpulkan dalam waktu yang bersamaan.
Dalam penelitian ini yang diteliti adalah keadaan bakteri Streptococcus mutans setelah diberi ekstrak biji mengkudu. Rencana penelitian yang dilakukan adalah eksperimen, pengamatan dengan kelompok kontrol dan dapat digambarkan dalam model rancangan model sebagai berikut :

$\begin{array}{lcc} & \text { Eksperimen } & \text { Postest } \\ \text { Kelompok perlakuan } & (\mathrm{X} 1) & \text { O-1 } \\ \text { Kelompok kontrol } & (\mathrm{X} 2) & \text { O-2 }\end{array}$

Keterangan :

$\left(\mathrm{X}_{1}\right)$ : Pemberian ekstrak biji mengkudu

O-1 : Pengamatan dan pengukuran area daya hambat

$\left(\mathrm{X}_{2}\right) \quad$ : Larutan Natruim Fisiologis

O-2 : Pengamatan kelompok control

Sampel dalam penelitian ini adalah bakteri Streptococcus mutans sebanyak $1 \mathrm{ml}$ yang dimasukan ke dalam cawan petri untuk didapatkan media suspens bakteri. Suspensi tersebut ditumbuhkan pada media PCA pada cawan petri yang kemudian dilakukan peletakan kertas saring pada media tersebut.

Dalam penelitian ini data yang diperoleh dari hasil pengukuran dan perhitungan dibuat dalam bentuk tabulasi, yang berbentuk tabel kemudian dibuat dalam bentuk prosentase. Dalam menganalisa data, penelitian mengunakan metode penelitian analisis deskriptif kuantitatif yaitu untuk mendapatkan gambaran daya hambat ekstrak biji mengkudu terhadap pertumbuhan bakteri Streptococcus mutans.

\section{HASIL DAN PEMBAHASAN}

Gambaran tentang daya hambat ekstrak biji mengkudu terhadap pertumbuhan bakteri streptococcus mutans telah dilakukan di Laboratorium Mikrobiologi Jurusan Keperawatan Gigi. Hasil penelitian dapat dilihat pada tabel berikut : 
Tabel 1. Rata-rata total daya hambat ekstrak biji mengkudu.

\begin{tabular}{lcc}
\hline \multicolumn{1}{c}{ Perlakuan } & $\begin{array}{c}\text { Daya hambat } \\
\text { Ekstrak biji } \\
\text { mengkudu }\end{array}$ & Kategori \\
\hline Rata-rata perlakuan ke-I & $8,62 \mathrm{~mm}$ & Sangat lemah \\
\hline Rata-rata perlakuan ke-II & $8,48 \mathrm{~mm}$ & Sangat lemah \\
\hline Rata-rata perlakuan ke-III & $8,4 \mathrm{~mm}$ & Sangat lemah \\
\hline Rata-rata perlakuan ke-IV & $8,50 \mathrm{~mm}$ & Sangat lemah \\
\hline Rata-rata perlakuan ke-V & $8,19 \mathrm{~mm}$ & Sangat lemah \\
\hline Rata-rata perlakuan ke-VI & $8,12 \mathrm{~mm}$ & Sangat lemah \\
\hline Rata-rata perlakuan ke-VII & $8,13 \mathrm{~mm}$ & Sangat lemah \\
\hline Rata-rata perlakuan ke-VIII & $8,19 \mathrm{~mm}$ & Sangat lemah \\
\hline Rata-rata total & $8,33 \mathrm{~mm}$ & Sangat lemah \\
\hline
\end{tabular}

Berdasarkan Tabel 1 di atas dapat dijelaskan bahwa rata-rata total daya hambat ekstrak biji mengkudu terhadap pertumbuhan bakteri Streptococus mutans adalah sebesar $8,33 \mathrm{~mm}$ kategori sangat lemah.

Tabel 2. Rata-rata daya hambat control Natrium fisiologis $0.9 \%$

\begin{tabular}{lcc}
\hline \multicolumn{1}{c}{ Perlakuan } & $\begin{array}{c}\text { Daya hambat } \\
\text { kontrol (Natrium } \\
\text { fisiologis 0.9\%) }\end{array}$ & Kategori \\
\hline Rata-rata perlakuan ke-I & $4,62 \mathrm{~mm}$ & Sangat lemah \\
\hline Rata-rata perlakuan ke-II & $4,65 \mathrm{~mm}$ & Sangat lemah \\
\hline Rata-rata perlakuan ke-III & $4,25 \mathrm{~mm}$ & Sangat lemah \\
\hline Rata-rata perlakuan ke-IV & $3,95 \mathrm{~mm}$ & Sangat lemah \\
\hline Rata-rata perlakuan ke-V & $4,5 \mathrm{~mm}$ & Sangat lemah \\
\hline Rata-rata perlakuan ke-VI & $3,8 \mathrm{~mm}$ & Sangat lemah \\
\hline Rata-rata perlakuan ke-VII & $4,17 \mathrm{~mm}$ & Sangat lemah \\
\hline Rata-rata perlakuan ke-VIII & $4,60 \mathrm{~mm}$ & Sangat lemah \\
\hline \multicolumn{1}{c}{ Rata-rata total } & $4,31 \mathrm{~mm}$ & Sangat lemah \\
\hline
\end{tabular}

Berdasarkan Tabel 2 di atas dapat dijelaskan bahwa rata-rata total daya hambat kontrol Natrium fisiologis $0,9 \%$ terhadap pertumbuhan bakteri Streptococus mutans adalah sebesar $4,31 \mathrm{~mm}$ kategori sangat lemah.

Berdasarkan hasil penelitian yang telah dilakukan di Laboratorium Mikrobiologi untuk mengetahui pengaruh ekstrak biji mengkudu terhadap daya hambat pertumbuhan bakteri Streptococcus mutans menunjukkan bahwa ada pengaruh ekstrak biji mengkudu terhadap bakteri Streptococcus mutans. Streptococcus mutans biasanya ditemukan pada rongga gigi manusia yang luka dan menjadi bakteri yang paling kondusif menyebabkan karies untuk email gigi (Salam, 2012).
Pada penelitian ini menunjukkan adanya kandungan kimia pada biji mengkudu yaitu Asam linoleat dan asam lemak esensial, alkaloid, saponin dan tanin. Tetapi yang bisa menghambat bakteri adalah zat tanin dan saponin. Tanin memiliki aktivitas antibakteri, secara garis besar mekanisme yang diperkirakan adalah toksisitas tanin dapat merusak membran sel bakteri, senyawa astringent tanin dapat menginduksi pembentukan kompleks ikatan tanin terhadap ion logam yang dapat menambah daya toksisitas tanin itu sendiri (Bayu, dkk, 2008). Saponin mempunyai efek antibakteri dan anti jamur yang bagus, efek anti jamur dan antibakteri terganggu dengan adanya gugus monosakarida dan turunannya (Dewi, 2009). Estrak maserasi menggunakan pelarut etanol $70 \%$, kemudian di rendam selama 24 jam untuk melarutkan zat-zat yang ada di dalam biji mengkudu.

Diameter zona terang (daya hambat) pada pengulangan I adalah $8,62 \mathrm{~mm}$, pengulangan II sebesar 8,48, pengulangan ke III sebesar $8,4 \mathrm{~mm}$, pengulangan ke IV sebesar $8,50 \mathrm{~mm}$, pengulangan ke $\mathrm{V}$ sebesar $8,19 \mathrm{~mm}$, pengulangan ke VI sebesar $8,12 \mathrm{~mm}$, pengulangan ke VII sebesar $8,13 \mathrm{~mm}$ dan pengulangan ke VIII adalah sebesar $8,19 \mathrm{~mm}$.

Menurut Greenwood dalam Pratama, (2005) Klasifikasi respon hambatan pertumbuhan bakteri yang memiliki diameter zona terang lebih dari $20 \mathrm{~mm}$ maka respon hambat pertumbuhan dikategorikan kuat, diameter zona terang 16-20mm dikategorikan sedang, diameter zona terang 10-15mm dikategorikan lemah, diameter zonaa terang kurang dari $10 \mathrm{~mm}$ dikategorikan sangat lemah, dan diameter zona terang 0 dikategorikan tidak ada respon hambat pertumbuhan bakteri.

Pada ekstrak biji mengkudu memiliki rata-rata zona hambat bakteri sebesar $8,33 \mathrm{~mm}$, maka untuk ekstrak biji mengkudu memiliki respon daya hambat pertumbuhan bakteri dalam kategori sangat lemah dan untuk kelompok kontrol adalah sebesar 4,31 $\mathrm{mm}$ masih dalam kategori sangat lemah, 
tetapi daya hambat bakteri lebih baik menggunakan ekstrak biji mengkudu dengan selisih sebesar 4,01\%. Perbedaan hasil pada penelitian dan kurangnya respon daya hambat ekstrak biji mengkudu disebabkan oleh kualitas ekstrak biji mengkudu yang kurang maksimal dalam menyari kandungan yang mempunyai antibakteri. Rendahnya nilai rata-rata daya hambat ekstrak biji mengkudu terhadap bakteri Streptococcus mutans menunjukkan bahwa bakteri kurang sensitif terhadap bahan uji.

Kelompok kontrol menggunakan Natrium fisiologis merupakan larutan isotonis yang memiliki banyak kegunaan dalam bidang medis dan laboratorium, dan umumnya larutan garam fisiologi memiliki kisaran konsentrasi 0.9\% (Anonim, 2014). Pada tabel di atas menunjukkan adanya daya hambat pada kelompok kontrol yaitu $4,31 \mathrm{~mm}$, adanya daya hambat bakteri karena Natrium fisiologis terdapat kandungan garam di dalamnya yang bisa digunakan sebagai antimikroba pada konsentrasi rendah air garam akan merangsang pertumbuhan bakteri. Namun sebaliknya, garam dalam bentuk murni dengan konsentrasi tinggi dapat bersifat toksik karena terdapat unsur Natrium chloride di dalamnya yang merupakan golongan halogen. Halogen memiliki sifat oksidator yang kuat dan mampu mematikan bakteri (Salam, 2012).

Kontrol yang digunakan pada penelitian ini adalah kontrol positif yaitu kelompok perlakuan yang besar kemungkinannya menghasilkan efek atau perubahan pada variabel tergantung. Kelompok kontrol positif bertujuan untuk membuktikan bahwa eksperimen yang anda gunakan sudah tepat dan dapat menghasilkan perubahan positif pada variable tergantung (Anonim, 2013).

Kecilnya zona hambat kemungkinan dipengaruhi oleh mutu ekstrak biji mengkudu. Dalam penelitian ini zat yang terkandung di dalam ekstrak biji mengkudu belum bisa ditentukan kadarnya, sehingga nilai daya hambat yang kecil dapat dikarenakan zat aktif saponin dan tanin yang terdapat dalam ekstrak biji mengkudu tidak dalam kadar yang cukup untuk menimbulkan efek antibakteri. Mutu ekstrak dipengaruhi oleh dua faktor yatu faktor biologi dan kimia. Faktor biologi meliputi spesies tanaman, waktu pemanenan, serta bagian tanaman yang digunakan. Faktor kedua adalah faktor kimia antara lain faktor eksternal dan internal. Faktor eksternal meliputi kandungan logam berat dan pestisida pada tanaman. Faktor internal yang mempengaruhi mutu ekstrak meliputi jenis, komposisi kualitatif, komposisi kuantitatif dan kadar rata-rata senyawa aktif yang terkandung dalam biji mengkudu (Sawiti, dkk, 2013).

Teknis penelitian pada pelaksanaan tidak dapat diperhitungkan yaitu meliputi kebersihan alat, ruangan yang tidak steril, suhu ruangan, waktu inkubasi, PH dari media dan kurangnya pengetahuan peneliti saat melakukan penelitian, juga dapat mempengaruhi hasil dari penelitian ini.

Hasil yang diperoleh menunjukkan bahwa rata-rata hasil pengukuran zona hambat bakteri mengalami perubahan atau tidak konstan, hal ini di karenakan faktor teknis yang terjadi pada saat penelitian, yaitu banyaknya ekstrak biji mengkudu yang terserap pada paper disk, sehingga kepekatan paper disk mengalami perbedaan dan berpengaruh pada daya hambat. Berdasarkan penelitian yang telah dilakukan menunjukkan bahwa bakteri Streptococcus mutans sensitif terhadap bahan uji. Hal ini dapat diamati dari zona hambat yang terlihat pada masingmasing perlakuan mengalami perbedaan daya hambat walaupun perbedaan hanya sedikit.

\section{KESIMPULAN}

1. Ekstrak biji mengkudu dapat menghambat pertumbuhan bakteri Streptococcus mutans dengan kategori sangat lemah.

2. Ekstrak biji mengkudu memiliki rata-rata daerah bebas bakteri Streptococcus mutans yaitu sebesar $8,33 \mathrm{~mm}$. 
3. Ekstrak biji mengkudu memiliki rata-rata daya hambat $8,33 \mathrm{~mm}$, sedangkan untuk kelompok kontrol Natrium Fisiologis $0,9 \%$ adalah $4,31 \mathrm{~mm}$.

\section{DAFTAR PUSTAKA}

Anonim, 1994, Buku Ajar Mikrobiologi Kedokteran, Edisi Revisi, Binarupa Aksara, Jakarta.

, 2010, Bakteri Dalam Rongga Mulut Kita, Gusimerah.blogspot.com, diakses tanggal 3 November 2014.

, 2012, Manfaat Buah Mengkudu, Termasuk Buah dan Bijinya, http://buahagia.blogspot.com/2012/08 /manfaat-buah-mengkudu.html, diakses tanggal 3 November 2014.

$$
2014
$$

Biji,

http://id.wikipedia.org/wiki/Biji, diakses 6 februari 2015.

2014, Larutan Garam Fisiologis, http://id.wikipedia.org/wiki/Larutan garam fisiologi, diakses tanggal 17 Mei 2015.

Anief, M., 2000, Ilmu Meracik Obat Teori dan Praktik, Gadjah Mada University Press, Yogyakarta.

Aryadi, I., G., Pengaruh ekstrak daun mengkudu (Morinda citrifolia, L.) terhadap

pertumbuhan

Staphylococcus Aureus sebagai penyebab abses periodontal secara in vitro, http://unmas-library.ac.id/wpcontent/uploads/2014/10/skripsi.pdf, diakses tanggal 17 Mei 2015.

Bangun, A, P., \& Sarwono, B., 2002, Sehat dengan Ramuan Tradisional: Khasiat danManfaatMengkudu, Agromedia Pustaka, Jakarta.
Bayu D, W., Malia, A., Aulia, I., Soko, A, P., 2008, Pengujian Efektivitas Tanin Sebagai Antibakteri, Institut Pertanian Bogor, http://repository.ipb.ac.id /bitstream/handle/123456789/36586/ pengujian\%20efektivitas\%20tanin $\% 2$ $0 \% 281 \% 29$.pdf?sequence $=7$, diakses 20 januari 2015.

Depkes RI., 2009, Tentang Kesehatan, pppl.depkes.go.id, diakses tanggal 3 November 2014.

, 2013, Tentang Gigi dan Mulut, www.depkes.go.id/ resources/download / general/Hasil Riskesdas 2013.pdf, diakses 19 Januari 2015.

Dewi, F., K., 2010, Aktivitas Antibakteri Ekstrak Etanol Buah Mengkudu (Morinda Citrifolia, Linnaeus) Terhadap Bakteri Pembusukan Daging Segar, Jurusan Biologi,FMIPA Universitas Sebelas Maret, Surakarta, http://eprints.uns.ac.id/388/1/1696823 09201001141.pdf, diakses tanggal 6 februari 2015.

Dewi, R, C., 2009, Uji Efektivitas Anti Jamur Ekstrak Buah Pare Belut, FMIPA Universitas Sebelas Maret, Surakarta, http.eprints.uns.ac.id, diakses 20 januari 2015.

Diah, U., Dewi, N., Moh Nur., Endang, S., 2014, Mengkudu (Morinda citrifolia $L)$, FakultasFarmasi UGM,http://ccrc.farmasi.ugm.ac.id/? page $\mathrm{id}=389$, diakses tanggal 3 Desember 2014.

Ditjen POM, 2000, Parameter Standar Umum Ekstrak Tumbuhan Obat, Cetakan Pertama, Jakarta, Departeman Kesehatan RI, Halaman 10-12. 
1986, Sediaan Galenik, Jakarta, Departeman Kesehatan RI, Halaman 10-11.

Djauhariya, E., \& Rosman, R., 2000, Status Perkembangan Teknologi Tanaman Mengkudu, Balai Penelitian Tanaman Obat dan Aromatik, http://balittro.litbang.pertanian.go.id/i nd/images/file/Perkembangan\%20TR O/edsus19n01/2Mengkudu.pdf, diakses 20 januari 2014.

Dwijoseputro, 1987, Dasar-Dasar Mikrobiologi, Djambatan, Surabaya.

Harmita \& Maksum R., 2008, Buku Ajar Analisis Hayati, EGC, Jakarta.

Hayani, E., \& Fatimah, T., 2004, Identifikasi Komponen Kimia Dalam Biji Mengkudu, Balai Penelitian Rempah dan Obat, Bogor, http://balitnak.litbang.pertanian.go.id, diakses tanggal 3 November 2014.

Kariman, 2014, Bebas Penyakit dengan Tanaman Ajaib, Open books, Surakarta.

Khomsan, A., 2009, Rahasia Sehat dengan Makanan Berkhasiat, Kompas, Jakarta.

Lubis, M., 2011, Tanin, Universitas Sumatra utara, repository.usu.ac.id/bitstream/12345 6789/22677/4/Chapter\%20II.pdf, diakses 20 Januari 2014.

Notoatmodjo, S., 2005, Metodologi Penelitian Kesehatan, Rineka Cipta, Jakarta.

Novel, S.S., Wulandari A.P., Safitri R., 2010, Praktikum Mikrobiologi Dasar, CV. Trans Info Media, Jakarta.
Nugraha, W., 2008, Streptococcus Mutans, Fakultas Farmasi USD, Yogyakarta, www.mikrobiologi.files.wordpress.co m/2008/05/streptococcus-mutans 31.pdf, diakses tanggal 3 November 2014.

Pratama, Moch Rachdie, 2005, Pengaruh Ekstrak Serbuk Kayu Siwak (salvadora persica) Terhadap Pertumbuhan Bakteri Streptococcus Mutans Dan Staphylococcus Aureus Dengan Metode Difusi Agar, http://skripsi.blogsome.com/2005/06/ 25/cover, diakses tanggal 4 November 2014.

Puspitasari, G., Murwani, S., Herawati, 2012, Uji daya antibakteri perasan buah mengkudu matang (Morinda citrifolia) terhadap bakteri Methicillin Resistan Staphylococcus Aureus (MRSA) M.2036.T secara in vitro, $\quad$ http://pkh.ub.ac.id/wpcontent/uploads/2012/10/0813100019 -Galuh-Puspitasari.pdf, diakses tanggal 17 Mei 2015.

Salam, F., 2012, Efektivitas Larutan Air Garam Terhadap Pertumbuhan Bakteri Streptococcus Mutans, http://repository.unhas.ac.id/handle/1 23456789/1053, diakses tanggal 17 Mei 2015.

Sawiti, M.Y., Mahatmi, H., \& Besung I.N.K., 2013, Daya Hambat Air Perasan Daun Sambiloto Terhadap Pertumbuhan Bakteri Escherichia coli, Jurnal Kedokteran, Fakultas Kedokteran Hewan, Universitas Udayana, Bali.

Syamsunir, 1992, Dasar-Dasar Mikrobiologi dan Parasitologi Untuk Perawat, EGC, Jakarta.

Volk \& Wheeler, 1990, Mikrobiologi Dasar, Erlangga, Jakarta. 
